University of South Florida

DIGITAL COMMONS

@ UNIVERSITY OF SOUTH FLORIDA
Digital Commons @ University of

South Florida

$12-1-2001$

\title{
2001 Florida Statewide Transit Training and Technical Assistance Program
}

CUTR

Follow this and additional works at: https://digitalcommons.usf.edu/cutr_nctr

\section{Scholar Commons Citation}

CUTR, "2001 Florida Statewide Transit Training and Technical Assistance Program" (2001). Research Reports. 206.

https://digitalcommons.usf.edu/cutr_nctr/206

This Technical Report is brought to you for free and open access by the National Center for Transit Research (NCTR) Archive (2000-2020) at Digital Commons @ University of South Florida. It has been accepted for inclusion in Research Reports by an authorized administrator of Digital Commons @ University of South Florida. For more information, please contact digitalcommons@usf.edu. 


\title{
ANNUAL PROGRESS REPORT For the Period of January 2001 through December 2001
}

\author{
Florida Transit Training Program (2001) \\ Florida Technical Assistance Program (2001)
}

The following progress report is intended to highlight the significant activities of the Florida Transit Training Program and Florida Technical Assistant Program for the 2001 year. Not all requests received are noted below.

The Florida Statewide Transit Training Program

- Negotiation Strategies in Public Transportation: Understanding the Present and Developing Breakthrough Strategies and Tactics; June 27-28, 2001.

This workshop was taught by Dr. Joseph Cronin of the Marketing Institute, Florida State University. Attachment $A$ is the class registration form/announcement. Attachment $B$ is the class roster. Attachment $C$ is the evaluation forms. Unfortunately, Dr. Cronin did not distribute evaluation forms during class. However, evaluation forms were developed by CUTR and later mailed to all who attended.

- It's A Matter Of..... Quality Customer Service; October 7-9, 2001

The Customer Service class a great success. Since there were so many people interested in attending, we had to expand the class size from 20 to 25 . Those who attended found it very informative and helpful. Several students suggested we offer the class in another location, so that others in their agencies could attend. Several transit agencies have requested that we offer this class in South Florida. Attachment $D$ is the class registration form/announcement. Attachment $E$ is the class roster. Attachment $F$ is the evaluation forms. Attachment $G$ contains copies of the certificates of completion, which were distributed to all the participants.

- Using Your Emotional Intelligence in Conflict Management; December 4-6,2001

We used this class as a beta test and offered it at the Dr. Alphonso Center on Fowler Avenue in Tampa. Enrollment for this class was slightly lower than usual. However, those who attended were very happy with what they learned.

Attachment $\mathrm{H}$ is the class registration form/announcement. Attachment $\mathrm{I}$ is the class roster. Attachment $\mathrm{J}$ is the evaluation forms. Attachment $\mathrm{K}$ is a copy of the certificates. 


\section{UPCOMING TRAINING}

- Land Threat Analysis and Incident Management, January 8-11, 2001. Instructed by Frank Montes De Oca. The flier and registration form for this class can be found in Attachment $\mathrm{L}$.

- Technology in Transit, February 12\&13, 2002, Instructed by Drew DeCandis. The flier and registration form for this class can be found in Attachment M.

- Managing Today's Transit Employees; The X-ers and the Boomers., June 12, 2002, Instructed by Dave Cyra. The flier and registration form for this class can be found in Attachment N. FPTA/ CUTR Professional Development Workshop.

- Alternative Fuels in Transit, Instructed by CUTR, June 10,2002. FPTA/ CUTR Professional Development Workshop.

- Bus Collision Prevention Awareness, Instructed by the Transportation Safety Institute, June 11, 2002. FPTA/ CUTR Professional Development Workshop.

- The Art of Delegation; Delegating for Results, Instructed by Dave Cyra, June 12, 2002. FPTA/ CUTR Professional Development Workshop.

- Bus System Safety, August 5-9, 2002, Instructed by the Transportation Safety Institute. The flier and registration form for this class can be found in Attachment O.

\section{Potential 2002-2003 Trainings}

- Effectively Managing Transit Emergencies (TSI)

- Fatigue Awareness Seminar (TSI)

- Contract Administration (NTI)

- Public Involvement in Transportation Decisions (NTI)

- GIS Application for Transit (CUTR) 
- Polk County National Transit Database Reporting; February 2001

CUTR provided assistance and training to Polk County regarding National Transit Database reporting. This included record keeping, standards, procedures, and definitions. Additionally, CUTR reviewed all demand responsive trip records for fiscal year 2000 and developed estimates from samples, based on UMTA Circular 2710.2A.

- Sarasota Area Transit (SCAT); May 14 \&15, 2001

SCAT requested technical assistance in the area of commuter feeder buses. CUTR staff was able to share their expertise and knowledge of similar services. Additionally, CUTR assisted SCAT with special considerations and issues that needed to be addressed.

All of the correspondence/ reports are in Appendix $\mathrm{P}$.

- PalmTran Citizen Advisory Board- Governance Subcommittee; May 2001

Palm Tran requested CUTR's assistance to shape alternatives and suggest improvements for their governance structure in Palm Beach County. CUTR met with the Palm Tran Citizen Advisory Board and created a brief report outlining alternatives and suggestions for their consideration (Appendix Q). Additionally, all of the correspondence and notes associated with this project can also be found in Appendix Q.

- Miami-Dade Paratransit Review; June 2001

Intellitran, the primary broker of services for MDT ADA complimentary paratransit services, informed the transit agency that their company was longer interested in being the paratransit broker for the region. As a result MDA contacted with Trapeze to conduct an on-site assessment of the paratransit operation. During the site visit, CUTR served as an intermediary between Trapeze and MDA and provided assistance to Trapeze in matters that are intrinsic to the Florida coordinated transportation program (the Trapeze representative was from Canada). CUTR also provided assistance to the Information Technology personnel of MDT who were charged with recommending new models of service delivery to MDT executive management.

A compete project overview report and all of notes and correspondence can be found in Appendix R. 
- Local Option Fuel Tax; July 2001

Due to a number of calls requesting information on local fuel tax options, FDOT requested that we research and create a report of local fuel tax revenue options. Attachment $S$ is a copy of this report. This report was distributed statewide.

- VOTRAN APTS Peer to Peer; July 2001

A number of Florida Transportation agencies are planning to expand their intelligent transportation systems. CUTR provided technical assistance and research in assessing, evaluating and prioritizing such improvements. Attachment T is copy of the Information Mission Report as well as all correspondence.

- Development of the Florida Public Transit System Anti-Terrorism Resource Guide; October 2001.

CUTR staff prepared this resource guide for Florida's transit systems to assist them in preparing counter- and anti-terrorism programs within their agencies. This guide contains information on federal and state anti-terrorism resources, provides documents to assist transit agencies in developing or enhancing security plans and procedures, and identifies upcoming and continuing training programs and seminars on transit system security and anti-terrorism planning.

A copy of this report is provided in Appendix U.

\section{- Florida Statewide Technical Assistance and training Program Brochure}

In an effort to make transit agencies aware of the services provided through the Technical Assistance Program, an in-depth, colorful brochure was developed. The brochure was distributed statewide and is typically available at statewide conferences and meetings.

A copy of this brochure is provided in Appendix $\mathrm{V}$. 
ATTACHEMENT A 


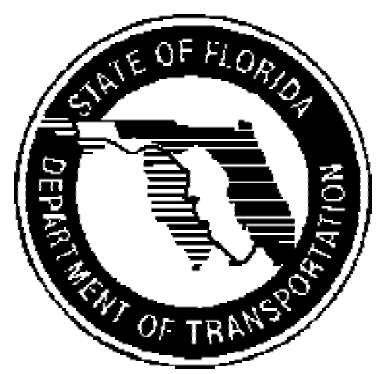

\title{
Negotiation Strategies in Public Transportation: Understanding The Present \& Developing Break Through Strategies and Tactics
}

\section{Florida Statewide Transit Training Program}

The Florida Department of Transportation, in cooperation with the National Center for Transportation Research at the Center for Urban Transportation Research and the Florida Transit Association will be sponsoring a two-day negotiation strategies workshop.

This two-day session, taught by Dr. Joseph Cronin of the Marketing Institute, Florida State University will identify challenges and approaches to conducting effective negotiations. The objective is to identify and apply break-through negotiation strategies and tactics for public transportation negotiations.

This course will be held on June 27-28, 2001 from 8:00-4:00 at the Center for Urban Transportation Research at the University of South Florida in Tampa. The workshop is limited to 30 participants so register early.

Registration is $\$ 25$ for the workshop. Please provide either check or purchase order made payable to the Florida Transit Association. Please mail registration fee along with the attached registration form to Amber Reep:

Florida Transit Association

\author{
c/o Center for Urban Transportation Research \\ University of South Florida \\ 4202 East Fowler Avenue, CUT 100 \\ Tampa, Florida 33620-5375
}

We have reserved a block of rooms at the Wingate Inn, $3751 \mathrm{E}$. Fowler Avenue (across from CUTR). The room rate is $\$ 69.00$. Specify group code CUT1 when making reservations to ensure proper rates. Please contact the Wingate Inn at (813) 979-2828. 


\section{REGISTRATION INFORMATION}

Registration Information: The course fee covers the cost of all course material and breaks. Participants are responsible for their own travel, accommodations, and meals. Register early to avoid any disappointment, as enrollment is limited to $\mathbf{3 0}$ per class. Directions to the training site will be included with your confirmation materials. This training facility is accessible to those with impairments. Please advise if you require special accommodations.

Refund Policy: Full refunds are possible if cancellation is received at least 14 business days prior to the event. No refunds will be given for cancellations made after June 7, 2001. If you register and are unable to attend, but will be sending a substitute, please advise the training coordinator, Amber Reep @ 813-974-9823 or at e-mail reep@cutr.eng.usf.edu

\section{How to Register:}

1. One form per registrant.

2. Please type or print clearly.

3. Send completed registration form and check or purchase order for $\$ 25$ to:

Florida Transit Association

c/o Center for Urban Transportation Research

University of South Florida

4202 East Fowler Avenue, CUT 100

Tampa, Florida 33620-5375

ATTN: Amber Reep

4. Registrations will be confirmed by mail. 


\section{REGISTRATION FORM}

Workshop Title Location Dates

\begin{tabular}{lll}
\hline Full First Name & Ml Last
\end{tabular}

Title/Position

Organization

Address

\begin{tabular}{lll}
\hline City & State & Zip Code
\end{tabular}

Business Phone

FAX

E-mail

\section{Method of Payment}

Tuition: $25 \$$

- Check Enclosed (made payable to the Florida Transit Association - federal identification number 591766032)

a Purchase Order Attached

\section{Type of Agency}

¿ Transit Agency

a MPO

- State DOT

a Consultant

- Other:

When Completed, Mail this form and registration fee to:

Florida Transit Association

c/o Center for Urban Transportation Research

University of South Florida

4202 East Fowler Avenue, CUT 100

Tampa, Florida 33620-5375

ATTN: Amber Reep 


\section{ATTACHMENT B}

Florida Statewide Transit Training and Technical Assistance Program, Annual Report 2001. National Center for Transit Research, Center for Urban Transportation Research, University of South Florida. 


\section{ATTACHMENT C}

Florida Statewide Transit Training and Technical Assistance Program, Annual Report 2001. National Center for Transit Research, Center for Urban Transportation Research, University of South Florida. 


\section{ATTACHMENT D}

Florida Statewide Transit Training and Technical Assistance Program, Annual Report 2001. National Center for Transit Research, Center for Urban Transportation Research, University of South Florida. 


\section{It's A Matter Of....Quality Customer Service}

The Florida Department of Transportation, in cooperation with the National Center for Transportation Research at the Center for Urban Transportation Research and the Florida Public Transit Association will be sponsoring a three-day quality customer service workshop.

This session, offered at the Center for Urban Transportation Research at the University of South Florida on November 7-9, 2001, will address the basic principle behind the phrase, "Quality Customer Service". You will learn to understand what your customers want and expect of your service as well as how to meet those demands. Emphasis will be placed on treating your customers like partners rather than adversaries and designing your service system so it is easy to use.

This workshop will identify many of the criteria required for this culture to be infused into the organization. Some of the topics to be discussed will include:

$\begin{array}{ll}\S & \text { Finding and retaining quality people } \\ \S & \text { Knowing customers intimately } \\ \S & \text { Focusing work units on customer satisfaction } \\ \S & \text { Training and supporting employees } \\ \S & \text { Creating easy-to-do-business/delivery systems } \\ \S & \text { Involving and empowering employees. }\end{array}$

\section{Registration Information}

Register early to avoid any disappointment, as enrollment is limited to 20 per class. Directions to the training site will be included with your confirmation materials. Please advise if you require special accommodations for a disability.

Refund Policy: Full refunds are possible if cancellation is received at least 14 days prior to the event. No refunds will be given for cancellations made after October 24, 2001. If you register and are unable to attend, but will be sending a substitute, please advise the training coordinator, Amber Reep, at (813) 974-9823 or reep@cutr.eng.usf.edu.

How to Register: One form per registrant. Please type or print clearly. Registrations will be confirmed by mail. Send completed registration form and check (made payable to the Florida Transit Association) or purchase order for $\$ 25$ to:

Florida Public Transit Association

ATTN: Amber Reep

c/o Center for Urban Transportation Research

University of South Florida

4202 East Fowler Avenue, CUT 100

Tampa, Florida 33620-5375

Florida Statewide Transit Training and Technical Assistance Program, Annual Report 2001. National Center for Transit Research, Center for Urban Transportation Research, University of South Florida. 


\section{REGISTRATION FORM}

Workshop Title

Location

Dates

Full First Name

MI

Last

Title/Position

Organization

Address

City

State

Zip Code

Business Phone

FAX

E-mail

\section{Method of Payment}

Tuition: $\mathbf{2 5 \$}$

- Check Enclosed (made payable to the Florida Transit Association - federal identification number 591766032)

口 Purchase Order Attached

\section{Type of Agency}

- Transit Agency

a MPO

a State DOT

a Consultant

○ Other:

When Completed, Mail this form and registration fee to:

Florida Transit Association

c/o Center for Urban Transportation Research

University of South Florida

4202 East Fowler Avenue, CUT 100

Tampa, Florida 33620-5375

ATTN: Amber Reep 


\section{ATTACHMENT E}

Florida Statewide Transit Training and Technical Assistance Program, Annual Report 2001. National Center for Transit Research, Center for Urban Transportation Research, University of South Florida. 
Lilly Agee

Customer Service Supervisor

Palm Tran, Inc.

3201 Electronics Way

West Palm Beach, FL 33407

561.841.4244

email:plwillia@co,palm-beach.fl.us

Eleanor Antokas

Transportation Services Supervisor

Pasco County Public Transportation (PCPT)

8620 Galen Wilson Boulevard

Port Richey, FL 34688

727.834.3200

727.834 .3344 (Fax)

Edie Biro

Paratransit Operations Supervisor

VOTRAN

950 Big Tree Road

South Daytona, FL 32119

$386.756 .7496 \quad \mathrm{x} 147$

386.756.7487 (Fax)

John Creaton

Transit Operations Analyst II

HARTline

4305 E. $21^{\text {st }}$ Avenue

Tampa, FL 33605

813.623.5835

email: creatonJ@hartline.org

Peggy Ewald

Assistant Transportation Manager

Pasco County Public Transportation (PCPT)

8620 Galen Wilson Boulevard

Port Richey, FL 34668

727.834 .3200

727.834 .3344 (Fax)

Beverly D. Godbolt

Transit Supervisor

City of Gainesville RTS

Post Office Box 490 - ST 5

Gainesville, FL 32602

352.334.2620

352.334.2607 (Fax)

Theresa C. Harrison

Transit Services Coordinator/Marketing

City of Gainesville RTS

Post Office Box 490 - ST 5

Gainesville, FL 32602

352.334.3676

email: harrisonTC@,ci.gainesville.fl.us

Florida Statewide Transit Training and Technical Assistance Program, Annual Report 2001. National Center for Transit Research, Center for Urban Transportation Research, University of South Florida. 
Melissa L. Hernandez

Secretary II

HARTline

201 E. Kennedy Blvd. Suite 900

Tampa, FL 33602

813.223.6831

email: hernandezm@hartline.org

Arthur Jacobs

Training Coordinator

Hillsborough County Specialized Transportation

4023 N. Armenia Avenue - Suite 300

Tampa, FL 33607

813.801.6813

email: jacobsa@hillsboroughcounty.org

Thomas Jury

Maintenance Manager Jacksonville Transportation Authority

100 N. Myrtle Avenue

Jacksonville, FL 32203

904.630.3140

email: tjury@jtaonthemove.com

George W. Kuyper

Transit Operations Superintendent

Sarasota County Area Transit

5303 Pinkney Avenue

Sarasota, FL 34233-2421

941.316.1007

email: Gkuyper@co.sarasota.fl.us

Rick Leavitt

Public Information Coordinator

HARTline

201 E. Kennedy Blvd. Suite 900

Tampa, FL 33602

813.223.6831

email: leavittr@hartline.org

Jesus Lopez

Dispatch/Scheduler

Flagler Senior Services

1000 Belle Terre Boulevard

Palm Coast, FL 32164

386.437.7276

email: lopez@flaglerseniors.org

Edgar Martinez

Manager

Hillsborough County Specialized Transportation

4023 N. Armenia Avenue - Suite 300

Florida Statewide Transit Training and Technical Assistance Program, Annual Report 2001. National Center for Transit Research, Center for Urban Transportation Research, University of South Florida. 
Tampa, FL 33607

813.276.8999

email: martineze@hillsboroughcounty.org

Luigia Schembri

Marketing Representative

HARTline

201 E. Kennedy Blvd. Suite 900

Tampa, FL 33602

813.223.6831

email:schembriL@hartline.org

Raul Silva

Operations Manager

Palm Tran CONNECTION

3040 So. Military Trail - Suite C

Lake Worth, FL 33463

$561.649 .9848 \times 3037$

email: rsilva@co.palm-beach.fl.us

Alvin R. Orgeron

Customer Service Coordinator HARTline

4305 E. $21^{\text {st }}$ Avenue

Tampa, FL 33605

813.623 .5835

email: OregeronA@hartline.org

Sandra T. Sloan

Paratransit Aide HARTline

4305 E. $21^{\text {st }}$ Avenue

Tampa, FL 33605

813.623 .5835

email: sloans@hartline.org

Darrell Smith

Service Planning Manager

Jacksonville Transportation Authority

100 N. Myrtle Avenue

Jacksonville, FL 32203

904.630.3153

email: dsmith@jtaonthemove.com

Walter Swepson

Marketing Representative

HARTline

201 E. Kennedy Blvd. Suite 900

Tampa, FL 33602

813.223.6831

email: SwepsonW@hartline.org

Roger Tillman

Transit Supervisor

Florida Statewide Transit Training and Technical Assistance Program, Annual Report 2001. National Center for Transit Research, Center for Urban Transportation Research, University of South Florida. 


\section{City of Gainesville RTS}

Post Office Box 490 - ST 5

Gainesville, FL 32602

352.334.2622

352.334-2607 (Fax)

Lorraine F. Toner

Transportation Operations Manager

Flagler Senior Services

1000 Belle Terre Boulevard

Palm Coast, FL 32164

386.437.7300

email: toner@flaglerseniors.org

Janet Wagnitz

Transit Operations Superintendent

Sarasota County Area Transit

5303 Pinkney Avenue

Sarasota, FL 34233-2421

941.316.1007

email: jwagnitz@co.sarasota.fl.us

Marlene J. Young

Transportation Manager

Jacksonville Transportation Authority

100 N. Myrtle Avenue

Jacksonville, FL 32203

904.630.3182

email: myoung@jtaonthemove.com

Pamela Young

Transportation Services Supervisor

Pasco County Public Transportation (PCPT)

8620 Galen Wilson Boulevard

Port Richey, FL 34668

727.834 .3200

727.834 .3344 (Fax)

Florida Statewide Transit Training and Technical Assistance Program, Annual Report 2001. National Center for Transit Research, Center for Urban Transportation Research, University of South Florida. 


\section{ATTACHMENT F}

Florida Statewide Transit Training and Technical Assistance Program, Annual Report 2001. National Center for Transit Research, Center for Urban Transportation Research, University of South Florida. 
ATTACHEMENT G

Florida Statewide Transit Training and Technical Assistance Program, Annual Report 2001. National Center for Transit Research, Center for Urban Transportation Research, University of South Florida. 


\section{ATTACHMENT H}

Florida Statewide Transit Training and Technical Assistance Program, Annual Report 2001. National Center for Transit Research, Center for Urban Transportation Research, University of South Florida. 


\title{
Using Your Emotional Intelligence \\ In Conflict Management
}

The National Center for Transit Research at the Center for Urban Transportation Research will be sponsoring a two-day conflict management workshop.

In today's transit environment it is not enough to know how to do your job or even to be a very intelligent person. People who are not emotionally smart waste time on personality conflicts and complaining. They lose self-control when faced with tense and stressful situations. "Unsmart" people undermine their own and other's performance and work satisfaction.

This two-day session, taught by Dave Cyra, is all about learning how to manage ourselves through self-awareness, self-regulation and motivation. In addition, we will review those skills that give us social competence-namely, empathy-and groom the individual to be adept at evoking desirable responses in others, especially in conflicting situations. Emotional competence is a learned capability based on emotional intelligence that results in outstanding performance at work.

This course will be held on December 4-5, 2001, at the Dr. Blaise F. Alfano Banquet \& Conference Center, 11606 Malcolm McKinley Drive, Tampa, Florida. The workshop is limited to 20 participants, so register early.

\section{Registration Information}

Participants are responsible for their own travel, accommodations, and meals. A block of rooms have been reserved at the Wingate Inn, 3751 E. Fowler Avenue, Tampa Florida. The rate is $\$ 69.00$ a night, please ask for group code "CUT5" when making reservations. Register early to avoid any disappointment, as enrollment is limited to 20 per class. Directions to the training site will be included with your confirmation materials. Please advise if you require special accommodations.

How to Register: One form per registrant. Please type or print clearly. Registrations will be confirmed by mail.

\author{
Center for Urban Transportation Research \\ ATT: Amber Reep \\ University of South Florida \\ 4202 East Fowler Avenue, CUT 100 \\ Tampa, Florida 33620-5375
}

Florida Statewide Transit Training and Technical Assistance Program, Annual Report 2001. National Center for Transit Research, Center for Urban Transportation Research, University of South Florida. 


\section{Registration Form}

Using Your Emotional Intelligence in Conflict Mgt. Tampa

Dec. $4-5,2001$

Workshop Title

Location

Dates

Full First Name

MI

Last

Title/Position

Organization

Address

City

State

Zip Code

Business Phone

FAX

E-mail

\section{Type of Agency}

口 Transit Agency

a MPO

a State DOT

a Consultant

口 Other:

** There is no registration fee for this class.

When completed, mail this form to:

Center for Urban Transportation Research

ATT: Amber Reep

University of South Florida

4202 East Fowler Avenue, CUT 100

Tampa, Florida 33620-5375

Florida Statewide Transit Training and Technical Assistance Program, Annual Report 2001. National

Center for Transit Research, Center for Urban Transportation Research, University of South Florida. 


\section{ATTACHMENT I}

Florida Statewide Transit Training and Technical Assistance Program, Annual Report 2001. National Center for Transit Research, Center for Urban Transportation Research, University of South Florida. 


\section{ATTACHMENT J}

Florida Statewide Transit Training and Technical Assistance Program, Annual Report 2001. National Center for Transit Research, Center for Urban Transportation Research, University of South Florida. 


\section{ATTACHMENT K}

Florida Statewide Transit Training and Technical Assistance Program, Annual Report 2001. National Center for Transit Research, Center for Urban Transportation Research, University of South Florida. 


\section{ATTACHMENT L}

Florida Statewide Transit Training and Technical Assistance Program, Annual Report 2001. National Center for Transit Research, Center for Urban Transportation Research, University of South Florida. 
LAND TRANSIT THREAT ANALYSIS AND INCIDENT MANAGEMENT

The Florida Department of Transportation in cooperation with the National Center for Transit Research at the Center for Urban Transportation Research will be hosting a Land Transit Threat Analysis and Incident Management class January 8-11, 2002.

\title{
$\underline{\text { Program Overview }}$
}

Preparation is a property's best defense against threat. This program will cover current issues and developing trends; and present options for the emergency planner and manager to consider when handling assets, property and equipment sites. Case studies and practical activities will be incorporated to allow participants the advantage of proactively developing action plans before an actual event. This four-day program, taught by FRM Associates, is targeted for contingency planners, crisis/consequence managers, safety officers, transit property supervisors and managers. The program will cover both conceptual aspects and practical applications of theory through practical exercises given on the final day of training.

\section{$\underline{\text { Topics Covered }}$}

- Threat Overview and Contemporary Terrorism

-Violence Against Land Transportation-A Historical Perspective -Bomb Threat Planning Recognition and Response

-WMD Awareness and Response

-Pre-Incident Indicator Awareness

-Transit System Vulnerability Assessment

-Special Events and Emergency Contingency Planning

-Media Relations

To Register: Please fill out the attached registration form and mail it and a $\$ 25.00$ (made payable to the Florida Public Transportation Association) to:

\author{
Center for Urban Transportation Research \\ University of South Florida \\ Attention: Amber Reep \\ 4202 E. Fowler Ave-CUT 100 \\ Tampa, Florida 33620
}

For additional information please contact Amber Reep at (813) 974-9823
ransit Yraining and Pechncal Assistance Program, Annual Report 2001. National 'esearch, Center for Urban Transportation Research, University of South Florida. 


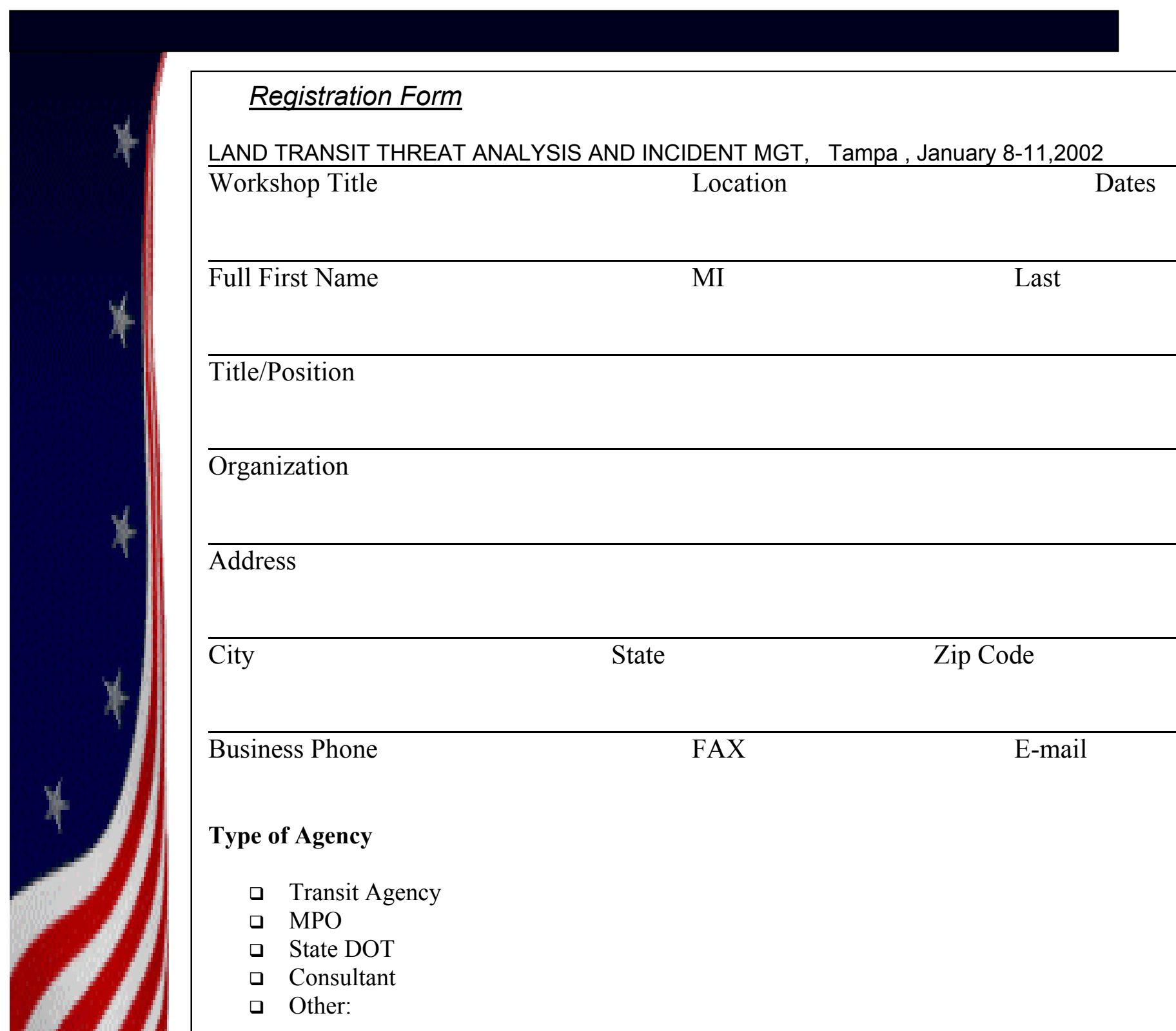

When completed, mail this form and $\$ 25.00$ registration fee to: (Checks made payable to Flo Public Transportation Association).

Center for Urban Transportation Research

ATT: Amber Reep

University of South Florida

4202 East Fowler Avenue, CUT 100

Tampa, Florida 33620-5375 


\section{ATTACHEMENT M}

Florida Statewide Transit Training and Technical Assistance Program, Annual Report 2001. National Center for Transit Research, Center for Urban Transportation Research, University of South Florida. 


\section{ATTACHMENT N}

Florida Statewide Transit Training and Technical Assistance Program, Annual Report 2001. National Center for Transit Research, Center for Urban Transportation Research, University of South Florida. 
The Florida Public Transit Association, in cooperation with Center for Urban Transportation Research and the Florida Department of Transportation will be sponsoring an four-hour management workshop at the FPTA/CUTR Professional Development Workshop June 10-12, 2002.

This four-hour session, offered at the Embassy Suites at the University of South Florida on June 12, 2002, will cover a trilogy of management training in three parts; Part One reviews the text "The Xers and the Boomers, From Adversaries to Allies - A Diplomat's Guide". In this first part we intend to study the role of a diplomat in working with the generations, helping them understand each other, getting them to communicate better, negotiating differences, resolving conflicts, and suggesting ways that they may better work together. The skills we hope to develop involve a better knowledge of different cultures, empathy, creativity, problem solving, rapport-building, listening, analyzing, and negotiating. With active participation, the attendees should be in a better position to view personnel problems with a new perspective. They should also be ready to negotiate solutions in their transit properties with those who report to them, those they report to, and their peers. With some practice they can become skilled in handling affairs without arousing hostility.

In Part Two, "Some Managerial Guides For Improved Job Performance", the facilitator will review six subjects that can serve as guides in any transit property. These subjects include:

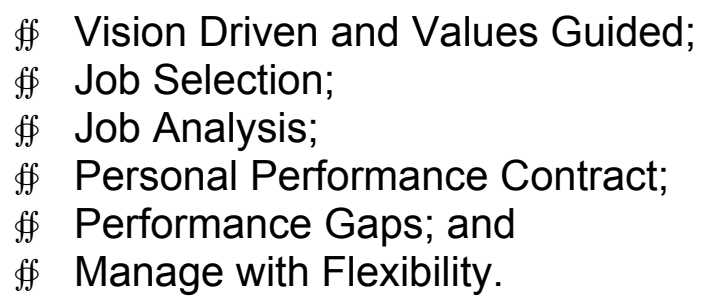

With very little study, the attendees will be able to take these guides and apply them in their own transit work environment. If information is power, this brief section is very powerful medicine for the ills that plague our transit work forces.

In Part Three, "managing Change", the workshop discusses how the pace of change is accelerating and how the demographic makeup of the workforce bears little resemblance to that of twenty years ago. The relationship between transit employees and their organizations is changing from one based on a long-term agreement to one that acknowledges the temporary nature of most transit liaisons. In the workshop the attendees will be instructed in how to make change work for them by simply facing the facts - to learn to accept the world as it isand then to look for ways to make reality serve them. The workshop is designed 
to help the attendee not only survive, but to thrive on ongoing change. In conclusion, the components of a change transition will be explored. This transition comprises of a preparation stage for oneself; the acceptance stage that includes initiation and support; and the commitment stage dealing with implementation and institutionalizing.

"Change is the only constant". The Greek philosopher, Heraclitus, made this comment 2,500 years ago. Change is the most pervasive influence within today's transit workplace. Profound changes are shaking up our lives and the way we provide transit service. Are you prepared?

\section{Registration Information}

Indicate on your FPTA/CUTR Registration forms that you would like to attend this class. Register early to avoid any disappointment, as enrollment is limited to $\mathbf{2 0}$ per class. Several weeks before the conference you will receive confirmation by mail.

Cancellation Policy: Since this course is limited to only 20 participation, if you register and don't attend others will have missed an excellent learning opportunity. If you register and are unable to attend, but will be sending a substitute, please advise the training coordinator, Amber Reep, at (813) 9749823 or reep@cutr.eng.usf.edu. 


\section{ATTACHMENT O}

Florida Statewide Transit Training and Technical Assistance Program, Annual Report 2001. National Center for Transit Research, Center for Urban Transportation Research, University of South Florida. 


\section{Transit Bus System Safety \\ (FT 00533)}

The Transportation Safety Institute (TSI) in cooperation with the Florida Department of Transportation and the Center for Urban Transportation Research will be hosting a Transit Bus System Safety (FT 00533) workshop in Tampa on August 5-9, 2002. This is a new TSI class and we are excited to be hosting it in Florida.

Course Description: This course presents a formalized, standardized approach to bus system safety concepts and program plans. Participants will receive instruction and guidance in developing and implementing a transit bus System Safety Program Plan which is critical to bus system safety.

Course Objective: Best practices in prevention of passenger incidents and vehicle collisions; Behavioral safety concepts; Safety awareness and management; Safety audits and checklists; Operator selection and employee training; Collision data tracking and trend analysis; Hazard analysis and resolution; Facility design; Routing and scheduling; Vehicle design, technology, selection, and maintenance; Facility operations security; Role in transit bus system safety: employees and management; Maintaining program effectiveness.

\section{Registration Information}

The course fee covers the cost of all course material and breaks. Participants are responsible for their own travel, accommodations, and meals. Register early to avoid any disappointment, as enrollment is limited to 12 per class. Directions to the training site will be included with your confirmation materials. Please advise if you require special accommodations.

How to Register: To register for this course, mail your registration form (attached) with the appropriate materials fee (\$45) to Amber Reep, Center for Urban Transportation Research, USF, 4202 E. Fowler Ave., Tampa, Florida 33620. Check or money orders must be payable to TSI Transit Safety \& Security Division. Your materials fee many also be processed with Visa or Mastercard. Registration will not be accepted by telephone. 


\section{ATTACHMENT P}

Florida Statewide Transit Training and Technical Assistance Program, Annual Report 2001. National Center for Transit Research, Center for Urban Transportation Research, University of South Florida. 


\section{ATTACHMENT Q}

Florida Statewide Transit Training and Technical Assistance Program, Annual Report 2001. National Center for Transit Research, Center for Urban Transportation Research, University of South Florida. 


\section{ATTACHMENT R}

Florida Statewide Transit Training and Technical Assistance Program, Annual Report 2001. National Center for Transit Research, Center for Urban Transportation Research, University of South Florida. 


\section{Statewide Technical Assistance Program}

In June 2000, Intellitran, the primary broker of services for MDT ADA Complimentary Paratransit Service, informed the transit agency that their company was no longer interested in being the paratransit broker for the region. Intellitran requested a transition that would end their contract with MDT by April 2002. Intellitran has six providers under contract to operate trips for them and, as an interim solution, Intellitran wished to assign the obligations of their contract over to a consortium company that was formed by the six contract providers. This action would enable the six providers to take over the brokerage responsibilities. In its letter to the MDT Board (the Miami-Dade Board of County Commissioners), Intellitran informed the County that this action was mandatory either the obligations were to be assigned to the consortium or Intellitran would simply cancel the contract outright.

In July, MDT contracted with Trapeze to conduct an on-site assessment of the paratransit operation. The site visit was scheduled for the week of July 16-20, and MDT requested that CUTR participate in the site visit. Bill Morris and Jennifer Hardin were the CUTR faculty who participated. During that week, interviews were scheduled with the following:

- MDT paratransit management personnel

- Reservations

- Information Technology

- Intellitran Management and Staff

- Transportation providers

During the site visit, CUTR attempted to provide assistance to Trapeze in interpreting interviewees when they spoke of matters that are intrinsic to the Florida coordinated transportation program (the Trapeze representative was from Canada). CUTR also provided much assistance to the Information Technology personnel of MDT whowere harged with recommending new models of service delivery to MDT executive management. This posedquite a challenge as the IT staff had to learn about paratransit in its entirety, which is a feat even for paratransit professionals in the field!

Also, during the site visit CUTR noted a huge risk inherent in the interim measures proposed by Intelletran to allow the consortium of transportation providers to take over the brokerage function. Specifically, MDT was going to place control of the client/tripdatabase, which contains client names, addresses, phone numbers, pick-up and drop-off times and locations, and other essential information, in the hands of the providers. CUTR caution MDT in the future, if MDT chose to transition the system to a new management structure, it would be in the interest of the providers not to surrender the database which wouldmean the loss of their business. Therefore, CUTR strongly urged MDT executive management to modify their contract with the consortium to expressly state that MDT is the exclusive owner of the database, that MDT must be 
allowed to conduct periodic back-ups, and that the consortium must surrender the database upon demand. MDT staff had not considered this risk and were appreciative of the advice.

Finally, the end result of the site-visit conducted by Trapeze was supposed to yield a report that would identify the most promising options available for an MDT reconstruction of the paratransit system. CUTR was never provided a copy this report and MDT staff indicated that they never received a product from Trapeze that they felt would meet their needs. The intent was to have CUTR assist in developing associated cost estimated associated with the service scenarios developed by Trapeze. Since July, MDT has decided that they will issue another RFP for a broker to manage and operate the paratransit system once the term of the interim solution has expired.

Florida Statewide Transit Training and Technical Assistance Program, Annual Report 2001. National Center for Transit Research, Center for Urban Transportation Research, University of South Florida. 


\section{ATTACHMENT S}

Florida Statewide Transit Training and Technical Assistance Program, Annual Report 2001. National Center for Transit Research, Center for Urban Transportation Research, University of South Florida. 


\section{ATTACHMENT T}

Florida Statewide Transit Training and Technical Assistance Program, Annual Report 2001. National Center for Transit Research, Center for Urban Transportation Research, University of South Florida. 


\section{Advanced Public Transportation Systems (APTS) Information Mission Ann Arbor Transit Authority Visit Ann Arbor Michigan - July 22-24, 2001}

\section{Background:}

A number of Florida Transportation agencies are planning and/or expanding intelligent transportation system components of their services and related support functions. CUTR is providing technical assistance and research in assessing, evaluating and prioritizing such improvements in an integrated and methodical fashion in conformance with federal and state procedures and standards.

In 1997, the Ann Arbor (Michigan) Transportation Authority (AATA) began deploying advanced public transportation systems (APTS) technologies in its fixed route and paratransit operations. The project's concept is the integration of a range of such technologies into a comprehensive system, termed the "Advanced Operating System" (AOS) that would enable "smart buses", "smart travelers," and a "smart operation center" to benefit from timely and coordinated information on critical aspects of transit operation and maintenance.

\section{Trip Purpose:}

To provide a hands-on experience of observing APTS in operation and a peer- to- peer discussion with Ann Arbor's Transit staff to understand technology development issues such as system implementation, O\&M impacts, customer reactions, organizational changes in roles \& responsibilities, benefits and lessons learned.

\section{Agency Participants (see attached individual list):}

VOTRAN SCAT

CUTR LYNX

Broward Transit

\section{Schedule / Travel:}

Travel Sunday July 22, 2001 for full day tour and discussion session on Monday July 23, 2001. Return Late Monday or Tuesday morning. Nearby Hotel: Fairfield Inn Ann Arbor. 
Ann Arbor (Michigan) Transportation Authority

(AATA) Visit

APTS Assessment Areas Outline

Agenda Discussion Topics

I. Review/Tour of System Categories: Experience, Benefits, Future Plans

a. Fleet Management Systems

b. Traveler Information Systems

c. Electronic Payment Systems

d. Transportation Demand Management

e. Transit Intelligent Vehicle Initiative

II. System Development Issues

a. Determination of Need / Improvement Justification

b. Goals and Objectives

c. Funding Approach / Resources

d. Procurement Specifications and acquisition

process

\section{System Implementation Issues}

a. Vendor Implementation Responsibilities \& Performance

b. Organizational Impacts

c. Budget \& Schedule experiences

d. In the "field" modifications and adjustments.

e. Review software enhancements \& special

programming.

f. Hardware improvements.

\section{Systems Evaluation and Continuous Improvement}

a. How, Who, and When of Evaluation Process

b. Review of Data Collection / Studies conducted

c. New system improvements - What's next? 


\section{Advanced Public Transportation Systems (APTS) Information Mission}

Ann Arbor Transit Authority Visit

Ann Arbor Michigan - July 22-24, 2001

Participant List

LYNX:

Edward Johnson $\quad$ 407-841-2279-x3058

Tori Iffland

Glen Waters

Ricky Sonny

Keith Tillet

Blanche Sherman

Endya Cummings

VOTRAN:

Jim Dorsten 386-756-7496-x128

Tom Stringer

SCAT:

Hank Cusak 941-316-1007

Broward:

Fabian Cevallos 954-357-8338

CUTR:

Rob Gregg

813-974-8383

Mark Mistretta

Ed Bart 
Observations and Findings

\author{
Advanced Public Transportation Systems (APTS) \\ Information Mission \\ Ann Arbor Transit Authority Visit \\ Ann Arbor Michigan - July 22-24, 2001
}

Overall Approach to APTS Development:

1- Start with the "Big Picture"; vision an entire system before you begin.

2- The most important objective was to obtain real time information for customer information benefits.

3- Involve Core Staff and capture buy-in from Board and Organizational functions.

4- Seek proven technology; pursue cutting edge, do not wander in to "bleeding edge."

5- Identify Core APTS system components and utilize prime vendors to ensure compatibility with tangent components.

6- Always be on the cutting edge of technology. Even after implementation, never stop looking for ways to improve the system.

7- Make employees aware that technology improvements are to help them do their jobs better, not to "catch" them.

8- It is extremely important to have an adequate training system to introduce and maintain new systems.

Procurement Approach:

1- Explain overall system approach and provide functional specifications to allow vendor flexibility to address needs.

2- Create a Procurement Team of procurement personnel, internal function users, and senior staff with vision and authority.

3- Be forceful with the vendors. Explain exactly what you want and get them to customize their product to fit your specific needs.

4- Demand customer service orientation from vendors.

5- Maintain a close working relation with vendor through installation and start-up. Require team approach so your staff learns from vendor. 


\section{Benefits/Technical Notes}

1- GFI fare-boxes were retrofitted to accept Smart Card options.

2- Multiple "smart" systems were sequenced to power-up in order to avoid sharp power drain and possible power short out.

3- Incorporate a rigorous test phase of systems in real operational environment to work out bugs in system or impact on existing systems.

4- Mobile Data Terminals (MDT) have become an important vehicle to vehicle communications especially with regard to customer transfers.

5- Monitoring engineering and transmission data may not be as significant a benefit as exploring trend analysis of part wear and preventative procedures.

6- Estimated investment with all smart system components $=\$ 25 \mathrm{k}-\$ 35 \mathrm{k}$ per vehicle.

7- There was a major focus on creating a state of the art training room, which had a operator display of all on vehicle components.

8- ATA staff seemed to be fully aware of system functions and extremely involved and happy with APTS efforts.

9- APTS data was continuously analyzed and used by planning staff to monitor and evaluate system performance.

10- Information System (IS) staff had an overall customer perspective and was responsible for more than just hardware and software installations. They were responsible for overall systems and focused on serving various functions in the organization. IS reported directly to the Executive Director. 


\section{ATTACHMENT U}

Florida Statewide Transit Training and Technical Assistance Program, Annual Report 2001. National Center for Transit Research, Center for Urban Transportation Research, University of South Florida. 


\section{ATTACHMENT V}

Florida Statewide Transit Training and Technical Assistance Program, Annual Report 2001. National Center for Transit Research, Center for Urban Transportation Research, University of South Florida. 